\title{
An Investigation into the Relationship between Emotional Labor and Customer Satisfaction
}

\author{
Bilal Mohammad Eneizan ${ }^{1}$, Asaad Ahmad abdelqader Alsakarneh², \\ Kamel A.AL-kharabsheh ${ }^{3}$, Hadi AL-Abrrow ${ }^{4}$, Alhamzah Alnoor ${ }^{5}$
}

Submitted: 25.07.2019. Accepted: 13.11.2019

\section{Abstract}

Purpose: This study primarily aims to provide insight into the role of deep acting and surface acting effects on customer satisfaction, with job satisfaction as the mediating and mentoring as the moderating variable.

Methodology: The study employs SPSS 21 for the analysis of data gathered with a survey questionnaire. The survey involved a sample of 291 employees of Jordanian service firms.

Findings: Obtained findings indicate significant direct relationships, with surface acting negatively related to both job satisfaction and customer satisfaction and deep acting positively related to both. The results support the mediating role of job satisfaction on the relationship between surface acting and customer satisfaction, along with deep acting and customer satisfaction. Moreover, the outcome substantiates the moderating role of mentoring on both acting types with job satisfaction.

Implication: This is the first study to empirically examine the mediating role of job satisfaction on the employee emotional labor relationship with customer satisfaction in service companies of a developing country.

Keywords: emotional labor, customer satisfaction, job satisfaction, mentoring

JEL: M10, M31

\footnotetext{
1 Jadara University, Irbid, Jordania; e-mail: Bilal.e@jadara.edu.jo.

2 PhD Student, School of Business, Central South University, China; e-mail: Asaadalsakarneh@yahoo.com.

3 Balqa Applied University, As-Salt, Jordania; e-mail: kamel@bau.edu.jo.

4 Corresponding author, Department of Business Administration, College of Administration and Economic, University of Basra, Basra, Iraq, Department of Business Administration, College of Administration Economic, University of Basra, Basra, Iraq; e-mail: hauni_2000@yahoo. com, https://orcid.org/0000-0003-1414-3283 .

5 Management Techniques Department, Management Technical College, Southern Technical University, Basrah, Iraq; e-mail: alhamzah. malik@stu.edu.iq.
} 


\section{Introduction}

Organizational emotions constitute a crucial research topic, particularly when in regard to organizational behavior. Employees in organizations go through different emotional experiences, whether their tasks pose a challenge to them, or they face an interactive process (Lin and Chang, 2015). Front line employees, who directly interact with customers, perceive emotional labor (EL) to be a significant matter, because emotions are a crucial part of employee work, particularly in the service industry that has proliferated in the modern society (Bitner et al., 1990). In the context of Jordan, the role of service workers experienced expansion, which proliferated the verbal and physical abuses piled up on service workers by customers. Hence, workers experience physical and mental stress that has now escalated into a social problem (Kim et al., 2012). Moreover, scholars describe EL as employee use of different strategies for emotional regulation in interaction with customers to meet the requirements of organizational emotional display; in short, to fulfill job requirements (Hochschild, 1983). Furthermore, EL may need one to express higher emotions, and it entails strict rules, diversity, and disharmony in emotions, which could result in a low level of satisfaction from work (Morris and Feldman, 1996). Some proved that the phenomenon could bring about burnout and depression (Kim et al., 2002), pervasive in all aspects of life. Others say it promotes an awareness of people, objects, and events that may influence thoughts, motivations, goals, and behaviors (Diefendorff et al., 2005).

In the hospitality industry, service workers must have the skills and training to provide excellent customer service (Purcell, 1993), and they are expected to follow the rules and regulations established by their workplace. Hence, employees experience EL as a reaction to their perceptions of the regulations (Diefendorff and Richard, 2003; Al-Abrrow et al., 2018). Emotional labor studies evidence that the display of positive emotions in interaction with customers (e.g., smiling and being friendly) is associated with positive customer return intention along with the intention to market the overall perception of the service quality received (Pugh, 2001). In other words, service workers' positive emotions in interactions with customers lead to higher customer satisfaction. Recent empirical studies evidence a positive relationship between emotional display rules and the use of emotional regulation strategies (Bozionelos and Kiamou, 2008) or between emotional regulation strategies and performance (Diefendorff and Richard, 2003). However, the identification of psychological processes entailed in emotional display remains largely untouched. Hence, there is little information available on whether emotional display influences employees affectively and behaviorally, and whether emotional display influences such outcomes. 
The subject of EL attracts increasing attention, as it is deemed a stress factor in public mental health, especially due to its potentially negative effect on employees. EL refers to the process by which workers must keep their feelings under control based on the demands of their organization and the role of their occupation (Brotheridge and Grandey, 2002). Nevertheless, scholars mostly investigate EL in relation to commercial and customer-service jobs, overlooking insurance employees.

There are two reasons behind the general interest in EL. First, EL is core to making profits and productivity. Second, EL is related to both job dissatisfaction and burnout (Bono and Vey, 2005). Past relevant studies show EL to lead to negative outcomes in health, psychology, well-being, job attitude, and employee performance. For instance, Johnson and Spector (2007) indicate that EL influences the well-being of employees, Kim (2008) evidences EL's impact on emotional exhaustion, while Yang and Chang (2008) report EL's influence on job satisfaction and employee organizational commitment. Other studies like the one by Ghalandari et al. (2012) evidence the impact of EL on the intention to leave and job performance, while Grandey et al. (2005) find EL to burden the performance of the whole organization.

Figure 1. Proposed conceptual model

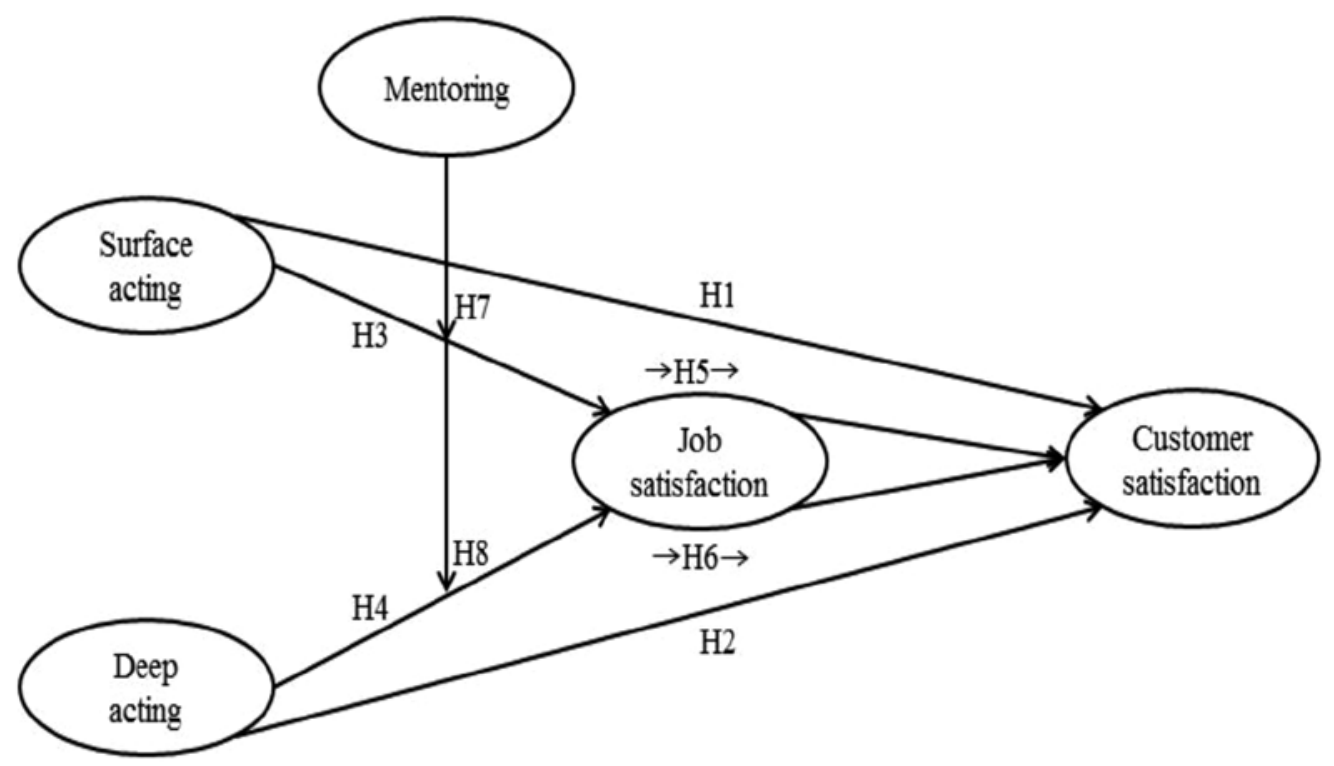

Source: own elaboration.

Studies devoted to examining the effects of EL in the service sector in light of job satisfaction and customer satisfaction are still scarce. Some focus on the relationship 
of EL with job performance, while only a few on the influence of EL on job and customer satisfaction. We focused on Jordanian service employees, because the sector is diverse in terms of employment, which means that it needs talented and capable people in nearly every area of the service industry. Thus, we conducted the current study in the service industry to achieve three objectives. First, to examine the relationship between EL (surface acting and deep acting) and customer satisfaction. Second, to scrutinize whether job satisfaction has a mediating role on the relationship between EL, job satisfaction, and customer satisfaction. Third, to inspect whether mentoring has a moderating role on the relationship between EL and job satisfaction. Figure 1 presents the hypothesized model for the above relationships. The next subsection provides a discussion on relevant theories and the development of hypotheses.

\section{Theory and Hypotheses Development}

\section{The Influence of Emotional Labor on Customer Satisfaction}

Several key definitions appeared for customer satisfaction. To begin with, Howard and Sheth (1969) refer to customer satisfaction as the buyer's cognitive state of being in/adequately rewarded for the sacrifice made in a buying situation (Yuksel and Yuksel, 2001). Moreover, others analyze the concept specifically in the field of operations management (Sáenz et al., 2018). Zhang et al. (2003) describe customer satisfaction as the level of customer perception of products and services as worth more than just the price. Customer satisfaction dimensions relate to the ratio of price to value, quality, loyalty, or performance of delivery (Yao et al., 2009). A good portion of literature is dedicated to emotional labor and its influence on the well-being of workers in light of the following: job stress (Grandey, 2003), job burnout (Brotheridge and Lee, 2002), job-induced tension (Liu et al., 2004), job satisfaction (Diefendorff and Richard, 2003; Al-Abrrow et al., 2019), and affective delivery (Grandey, 2003). Nevertheless, limited studies consider the effect of emotional labor on customer loyalty intention, service quality, and customer satisfaction (e.g., Hennig-Thurau et al., 2006; Groth et al., 2009). More specifically, Hennig-Thurau et al. (2006) reveal that the authenticity (deep acting) of employee emotional labor directly affects the emotional states of customers in a simulated service interaction, whereas Groth et al. (2009) show that - individually - emotional labor strategies of employees (deep and surface acting) have a distinct influence on customer satisfaction, with deep acting having a positive relationship with positive results of service delivery (e.g., perceived customer orientation and quality of service).

The source EL relies on the premise that effective emotional regulations of service workers have a major role in service interactions, while such regulations influence 
customer emotions, attitudes, and behaviors. In turn, EL influences customer satisfaction with received services. In fact, scholars prove that emotion management among service employees is a requirement in customer loyalty maintenance (Albrech and Zemke, 1985; Schneider and Bowen, 1985), because the emotional cues of service workers displayed to customers impact the latter's assessment of events (Schmit and Allscheid, 1995). Customer satisfaction measurement bases on customer expectations and performance perceptions, although not openly acknowledged by researchers, as some of them argue that customer satisfaction is akin to the concept of service quality (Yuksel and Yuksel, 2001). This is because the definitions of both concepts allude to comparisons between customer expectations and their perceptions of the actual product's performance (Iacobucci et al., 1995).

In a related study, Oliver (1993) explains that - in contrast to service quality - non-equality issues may influence judgments of satisfaction, because perceptions of satisfaction require one to experience the service provided, and various factors may have a hand in creating satisfaction. This is a premise supported by other studies that view perceived service quality as an attitude while viewing satisfaction as linked to a business transaction (Bitner, 1990; Bolton and Drew, 1991). As for cognitive and emotional evaluations of customers - with regards to the expectations and needs met by the product/service (Wilson et al., 2012) - customers often view employee emotional displays and its regulation as part and parcel of service provision (Grove and Fisk, 1992). Such perception produces a specific degree of expectations concerning the positive emotional expressions of workers, which eventually influences customer satisfaction levels (Tsai, 2001). In other words, customer satisfaction greatly depends on the attitudes and behaviors of employees (Wharton and Erickson, 1993).

Moreover, the emotional service worker-customer interaction generally affects the service experience of the latter along with his/her perception of the service quality; a finding supported by Bowen (1990) and Tsai (2001). In this regard, as we mentioned above, customer satisfaction is gauged by comparing consumption, expectation, and experience, which most deem to be achieved when the final outcome meets expectations (Khristianto et al., 2012; Alnoor et al., 2018). Others contend that the emotional regulation of employees in service interactions with clients influences the clients' outcomes (customer satisfaction), which are crucial for successful service. In the same vein, emotional labor strategies employed by employees - like displaying genuine emotion (deep acting) or fake emotion (surface acting) - influence customers in different ways. Customer satisfaction is a major factor in business profitability (Guo et al., 2012), because satisfied customers have a higher likelihood of making repetitive purchases compared to their dissatisfied counterparts (Garcia et al., 2012). 
Surface acting concentrates on customer response that appears after employees modify their visible expressions on the surface without showing what they really feel on the inside (Grandey, 2003). Bluntly put, surface acting of service employees limits their negative emotions to only display positive emotions, as if they put on masks in front of customers, without displaying their actual feelings (Grandey, 2003). The expression of fake emotions is known as "bad faith," when service workers deceive customers with their emotions (Rafaeli and Sutton, 1987). On the other hand, deep acting attempts to change the inner emotional state of employees by modifying antecedents like a situation or its perception in order to display authentic emotions (Grandey, 2003).

Customer satisfaction evidently plays a key role in consumer perception and judgment, which could lead to repetition in purchases. Currently, end-user experience became the central factor in businesses as the end-user decides which services and products to purchase. Thus, new product characteristics - like quality, perceived ease of use, appeal, aesthetics, or value for money - must be met to exceed customer expectations of products/services. For enhanced business performance and consumer satisfaction, organizations should have a deep insight into the satisfaction antecedents in the environment (Tandon et al., 2018).

Behind the purpose of deep acting is the genuine display of feelings to the customer; to satisfy the desired display rules laid out by the organization. This makes deep acting a "good faith," as employees must motivate themselves to have better emotions (Diefendorff et al., 2005) that could positively influence customer satisfaction. Considering the above discussion, this study proposes the following hypotheses:

H1: Surface acting is negatively related to customer satisfaction.

H2: Deep acting is positively related to customer satisfaction.

\section{Influence of Emotional Labor on Job Satisfaction}

According to Gosser and Diefendorff (2005), EL calls for displaying organizational rules notwithstanding employee emotions, and it requires them to follow emotion regulation work strategies. In theory, some mechanisms explain EL engenders burnout among employees (Brotheridge and Lee, 2002). The majority of works dedicated to EL strategies concentrate on two - surface acting and deep acting - most commonly used to regulate emotional work displays. In surface acting, the individual's actual emotions are especially suppressed and replaced with the desired yet fake ones; meanwhile, in deep acting, the desired emotions are experienced genuinely (Diefendorff et al., 2005; Chen et al., 2012). The experience of interpersonal stressors is acknowledged among the top stress 
sources that threaten one's self-image and may result in heightened cortisol-response and perceived distress in comparison to other stressors (Almeida, 2005). Using emotional strategies seeks to change emotional displays to align them with the display of rules established by the organization and, as a consequence, continuous stress exposure due to excessive emotional demands may trigger the stress system in the body (Lim et al., 2016).

More importantly, the majority of studies evidences the positive and negative consequences of emotional labor in job satisfaction, according to the EL form adopted by employees. Prior studies generally agree that deep acting results in positive outcomes, such as increased service performance and job satisfaction, while surface acting results in negative outcomes, such as deviant service behaviors and burnout. In particular, Totterdell and Holman (2003) report that deep acting increases service performance. Moreover, employees who engage in EL suffer from job dissatisfaction compared to those who do not. Studies show the negative correlation of surface acting with job satisfaction and its positive correlation with deep acting. Meanwhile, Kaur and Malodia (2017) indicate that job satisfaction may be increased by the use of EL and the relationship of EL with work conditions like job involvement, autonomy, self-monitoring, and identification with the organization; they all appear to increase the complication of EL relationship with job outcomes.

Moreover, Bono and Vey (2005) find surface acting to be significantly related to decreased job satisfaction, with deep acting being a non-factor. Hulsheger and Scehwe's (2011) meta-analytical regression analysis shows the same result. However, the differences in the findings of prior studies call for an in-depth examination in the public service context. In relation to this fact, studies confirm the threat of surface acting on job satisfaction among public service employees (e.g., Hsieh et al., 2012; Sloan, 2014), upon which the authors conclude that hypocritical acting indicates self-denial that has an adverse impact on job attitudes (Shamir, 1991). Current scholarship deep acting effects are still ambiguous.

In a related study, Dick (2011) determines the top most frequent EL strategies used by mental health workers as they interact with their patients, with outcomes ranging from burnout to job satisfaction. Moreover, employees who engage in deep acting are found by Lee and Ok (2012) to have a higher likelihood of being satisfied with their jobs in comparison to their surface acting counterparts. In a similar vein write Kim (2008) and Lee and Ok (2014; 2015), whose findings indicate that surface acting may lead to tension, stress, poor service quality, job dissatisfaction, burnout, and service misbehavior. According to a study of the same caliber, surface acting is not a good experience to feel, as employees force themselves to manage their emotions and fake their way 
to display positive emotions while limitations accumulate stress, eventually causing their dissatisfaction (Grandey, 2000; Abdulaali et al., 2019).

Furthermore, the meta-analysis conducted by Bono and Vey (2005) finds the same negative consequence of surface acting and job satisfaction. According to them, perceived negative display rules are not expected to produce the same effect on job satisfaction, as Bono and Vey focus on the negative emotions of individuals. In the work environment, such rules engender labor burden, as workers must focus on their outward expression and control negative feelings like sadness, anger, concern, or even fear (Hsieh, 2014). In this regard, surface-acting leads to repeated emotional dissonance of employees during customer interactions, so much so that they feel intense psychological and emotional distress and eventually lose control of their emotions.

Because employees who surface act experience the draining of psychological energy, they may not have the ability to harness their emotional resources and steer clear of further drain; they become disinclined to interact with customers, treat them in a callous manner, or dehumanize own perception of others. Such employees may also experience a limited sense of personal achievement from an unsuccessful performance on the job and minimized productivity, which rank among the top job dissatisfaction sources. In contrast, employees who try to understand the perspective of the customer through deep acting often do not experience emotional dissonance but, instead, feel emotional consonance, as they evoke real emotional displays in agreement with the required organizationally established emotions. In this way, customers react well to positive and sincere emotional expressions generated from deep acting while their needs are being met. According to Lee and Ok (2012), this results in the heightened confidence and personal achievement of employees, which also means their job satisfaction. Thus, the current study proposes the following hypotheses:

H3: Surface acting is negatively related to job satisfaction.

H4: Deep acting is positively related to job satisfaction.

\section{Job Satisfaction as a Mediating Variable}

Surface acting of employees entails the modification of emotional displays without actually changing their inner and actual feelings. In surface acting employees generally adhere to display rules to maintain their jobs, but not because they are concerned with the organization's customers (Chen et al., 2012). Such employees fake their emotions, thus decreasing the authenticity of service quality. According to Grandey (2003), there is a negative relationship between surface acting and service performance. In 
relation to this, Leiter et al. (2013) explain that burnout is quite a significant social concern, as evidenced by the attention it receives from scholarship in the past decades. In fact, a significant impact of burnout is its impact on job satisfaction among employees, as Hombrados-Medieta and Cosano-Rivas (2013) report. Surface acting employees control and suppress their negative moods but use superficial expressions that can easily crack and, as such, prior findings provide a direct link (Grandey, 2003). Others also propose the job satisfaction as a mediator, because surface acting affects job performance by confining positive attitude to the job but increasing emotional exhaustion level.

Similarly, deep acting may directly influence service performance rating, whenever employees attempt to change their feelings or internalize them in order to evoke feelings aligned with the required ones. Such good intentions generally result in providing higher service quality with the employees feeling empathy for the concerns of higher quality customers, which would benefit the whole organization (Grandey, 2000). With burnout, employees suffer from the long-term consequences of aversive working conditions, characterized by the symptomatic experience of exhaustion and job disengagement (Demerouti et al., 2010). Employee participation in decision-making using clear communication would make them feel important and satisfied with their jobs, which will make them do above and beyond to meet the expectations of their organization (Piccolo et al., 2010).

In line with Ashforth and Humphrey (1993) are Gosser and Diefendorff (2005), who evidence a direct, positive relationship between deep acting and service performance among working adults from different professions (services and sales, professionals, technical, management, clerical, education and healthcare). Exhaustion normally ensues after intensive physical, affective, or cognitive stress experienced after long-term exposure to job demands. Moreover, disengagement from the job occurs when employees distance themselves from the work objective, content, or work as a whole.

This study seeks to represent the required outcomes and behaviors that directly serve organizational goals. We emphasize the instrumentality of individual performance in organizational goals, as - despite its importance - the literature must yet provide a description of the whole human work performance range. Modern economic turmoil and dynamic technological developments make firms expect employees to be adaptive. Hence, notwithstanding the global economic crisis (2008), pressures increase towards efficiency, costs minimization, and new means of working (at any time, place, and with any tool; Brummelhuis et al., 2012), which enables increased work flexibility. Shafer (2002) reports a positive job satisfaction relationship with job performance, with managers promoting job performance of employees by utilizing strategies to facilitate job satisfaction among them (Springer, 2011). 
In relation to the above, highly satisfied employees work above and beyond their work descriptions to increase overall work productivity. According to Chen et al. (2012), job satisfaction positive affects job performance. The adaptive habits of employees at work can be conceptualized as a positive attitude to changes in the organization or modification of behaviors (Van den et al., 2013). Hence, deep acting on service outcomes may be mediated by satisfaction on the job, so we propose the following hypotheses:

H5: The relationship between surface acting and customer satisfaction is mediated by job satisfaction.

H6: The relationship between deep acting and customer satisfaction is mediated by job satisfaction.

\section{The Moderating Effect of Mentoring on the Relationship Between Emotional Labor and Job Satisfaction}

Employees can be mentored when it comes to interpersonal social resources in the form of support for working relationships and coaching, which allow them to address their emotional demands in jobs related to customer interaction (Chi and Wang 2016). In this regard, a mentor is an individual that provides different functions of support, guidance, protection, exposition, and counsel for efficient working among young adults (Weng et al., 2010). Mentoring refers to the interpersonal work relationship, in which an experienced senior worker supports less experienced colleagues in developing their careers/professions (Thomas and Lankau, 2009).

There are several mentoring functions that the literature highlights, which include psychosocial support, counseling to employees, friendship, and encouragement to enhance their perceived psychological and social support (Scandura and Ragins, 1993). For instance, the psychosocial support provided by mentors can give employees a sense of trust and assistance in their jobs (Kram, 1985).

Moreover, the mentor's job is to pave the way for the employees to enter social networks, including 1) repositories of information that cannot be accessed via formal channels of communication (Dreher and Ash, 1990); 2) career development to develop the employee's career via coaching and sponsorship; 3) mentors are the employee's role models as they show suitable attitudes and behaviors (Young and Perrewe, 2004; Johnson and Ridley, 2015; Erdem and Aytemur, 2008; Alhamdi et al., 2019).

Evidence shows that mentored employees experience higher levels in job satisfaction (e.g., Collins, 1994), with the psychosocial support provided by the mentor, which 
enhances the personal resources of employees for them to engage in deep acting (Schaufeli and Taris, 2014). Positive treatment and support from mentors can lead to positive work mood among employees (Cole et al., 2006). Mentoring functions - including protection, coaching, exposure, and role modeling - are linked to higher satisfaction on the job (Scandura and Viater, 1994), which minimizes the gap between experienced moods and required expressions, while making it easy for employees to employ deep acting. Moreover, learning from mentors can help clarify employees what customers think, so that the employees can reevaluate service situations and improve their deep acting effectiveness. In mentoring, protection entails mentors' exercise of protective methods and behaviors through which the employees learn new skills/tactics to protect them from damaging contact with key actors, which eventually leads to job satisfaction. As a coach, the mentor guides, listens, questions, praises, develops rapport, encourages, trusts, supports, and allows employees to focus on potential job opportunities that could increase their satisfaction. Mentors may also make employees more visible at work by appropriating important responsibilities and frequently complimenting them through the progress report to raise their job satisfaction. In some instances, mentors sponsor their protégés in challenging assignments, which further contributes to the latter's satisfaction (Lee and Montiel, 2011; Alhamdi et al., 2019).

Furthermore, the activity of counseling intends to engender mentee satisfaction through the use of client problem-solving and decision-making skills. The friendly attitude and role model acting of the mentor can also contribute to mentee job satisfaction. When mentees experience the proper use of mentoring functions like the ones mentioned above (role modeling, acceptance, friendly attitude), their job satisfaction rises (Jung and Tak, 2008; Lentz and Allen, 2009). The mentor builds value and character of protégés by being a role model, which results in the latter's sense of job satisfaction. Many studies dedicated to this topic show the increase of job satisfaction among mentees through mentoring (Allen et al., 2004). Lastly, Ashforth and Saks (2002) explain that mentee observance of and learning from their mentor's attitudes and behaviors enables them to identify and understand the service norms and values in the organization and, thus, to effectively modify their cognitions and thoughts to pursue excellence in services by focusing on customer needs, resolving their problems, and optimal service. Thus, this study proposes the following hypotheses:

H7: Mentoring moderates the negative relationship between surface acting and job satisfaction.

H8: Mentoring moderates the positive relationship between deep acting and job satisfaction. 


\section{Research Methodology}

This study employed the survey method as the data collection tool and - accordingly - developed a questionnaire with items adapted from different literature. The entire items were measured using a 5-point Likert scale and, in effect, quantitative techniques were used to analyze the responses. The survey took prior consent from respondents to collect and use their data in the current study. The participants received all relevant information about the study and that their informed consent was implied through survey completion. Data were analyzed using SPSS. From the distributed 400 questionnaires, we retrieved 291, thus obtaining a rate of response of $70 \%$. The respondents were selected randomly, while the questionnaire's validity and reliability were confirmed through a pre-test and pilot study. We conducted data analysis by employing demographic analysis to provide a description of the respondents' demography. The rest of the data concerning constructs were exposed to descriptive statistics, correlation, and regression analysis. The mediating role of job satisfaction was tested with the method proposed by Baron and Kenny (1986), whereas the moderating role of mentoring was tested using the interaction terms technique.

To confirm scales' validity and reliability, measurement items were adapted from literature sources. In particular, surface acting and deep acting items were adapted from the study by Diefendorff et al. (2005), job satisfaction items from Choo et al. (2009), customer satisfaction from Stathopolou and Balabanis (2016), and items that measured mentoring from $\mathrm{Hu}$ et al. (2011).

\section{Research Analysis and Results}

Table 1. Demographic Profile of the Participants

\begin{tabular}{|l|c|c|c|}
\hline \multirow{2}{*}{ Respondent's Profile } & Frequency & Percentage (\%) \\
\hline \multirow{3}{*}{ Gender } & Male & 163 & 56.0 \\
\hline & Female & 128 & 44.0 \\
\hline \multirow{2}{*}{ Age } & $20-30$ & 93 & 32.0 \\
\hline & $31-40$ & 116 & 39.9 \\
\hline & $41-50$ & 54 & 18.6 \\
\hline
\end{tabular}




\begin{tabular}{|l|l|r|r|}
\hline \multirow{3}{*}{ Income } & Below $\$ 500$ & 74 & 25.4 \\
\hline & $\$ 501-\$ 1000$ & 145 & 49.8 \\
\hline & Above $\$ 1000$ & 72 & 24.7 \\
\hline \multirow{2}{*}{ Education } & Undergraduate & 75 & 25.8 \\
\hline & Postgraduate & 144 & 49.5 \\
\hline
\end{tabular}

Source: own elaboration.

The results of the demographic analysis indicate that, among the 291 respondents, male respondents constituted $56 \%$, while the remaining $44 \%$ were female respondents. 93 of the respondents were aged between 20-30, 116 were aged between 31-40, and 54 between 41-50. The remaining 28 of the respondents were over 50 years of age. With regards to their income, $25 \%$ of the respondents had $\$ 500$ or lower income, $50 \%$ had $\$ 501$ to $\$ 1000$ income, and $25 \%$ had an income of over $\$ 1000$. $26 \%$ of all respondents held undergraduate degrees, $50 \%$ received postgraduate education, while the remaining $24 \%$ other education.

Table 2. Reliability Analysis and Descriptive Statistics

\begin{tabular}{|l|l|l|l|l|l|l|l|}
\hline Variables & $\begin{array}{c}\text { No. of } \\
\text { Items }\end{array}$ & Mean & $\begin{array}{c}\text { Standard } \\
\text { Deviation }\end{array}$ & Skewness & $\begin{array}{c}\text { Kolmogorov } \\
- \text { Smirnov }\end{array}$ & $\begin{array}{c}\text { Inter-Items } \\
\text { Coefficiencts }\end{array}$ & $\begin{array}{c}\text { Cronbach } \\
\alpha\end{array}$ \\
\hline SA & 04 & 2.7569 & 1.10268 & .160 & 0.11 & 0.586 & 0.851 \\
\hline DA & 04 & 3.0507 & .94789 & -.023 & 0.07 & 0.500 & 0.801 \\
\hline JS & 04 & 3.5619 & 1.07581 & .049 & 0.11 & 0.633 & 0.872 \\
\hline CS & 04 & 2.9187 & 1.1186 & -.393 & 0.10 & 0.491 & 0.795 \\
\hline MEN & 04 & 2.9296 & 1.0788 & .123 & 0.09 & 0.631 & 0.872 \\
\hline
\end{tabular}

Note: $S A=$ Surface Acting, $D A=$ Deep Acting, JS = Job Satisfaction, $C S=$ Customer Satisfaction, MEN= Mentoring. Source: own elaboration.

The above table displays the descriptive analysis results, with mean values ranging from 2.75 to 3.56 and standard deviation ranging from 0.94 to 1.11. Skewness values were absolute from 0.023 to 0.393 , which indicates good factor indicators. We ran the Kolmogorov-Smirnov Test to reveal a good significant result (p-value $>0.05$ ) of the entire variables (refer to Table 2). The study used Cronbach's alpha coefficient to confirm the items' internal consistency. Cronbach's alpha values should ideally be above 0.70, as suggested by Pallant (2011). In this study, the values of Cronbach's alpha were far from the cut-off, ranging from 0.79 to 0.87 . This supports strong consistency among 
items for every factor (refer to Table 2). The inter-item correlations were also gauged, considering the number of scale items was less than ten. A strong correlation occurs when the values range from 0.2 to 0.5 . In this study, the inter-item correlation ranged from 0.49 to 0.63 , which confirms a strong inter-item relationship.

\section{Table 3. Correlation Matrix}

\begin{tabular}{|l|l|l|l|l|}
\hline & JS & CS & SA & DA \\
\hline JS & 1.00 & & & \\
\hline CS & $.588^{* *}$ & 1.00 & & \\
\hline SA & -.107 & $-.152 * *$ & 1.00 & \\
\hline DA & $.405^{* *}$ & $.340 * *$ & $.149 *$ & 1.00 \\
\hline
\end{tabular}

* Correlation is significant at the 0.05 level (2-tailed).

** Correlation is significant at the 0.01 level (2-tailed).

Source: own elaboration.

The strength and direction of the linear relationship between dependent and independent variables are generally determined by the correlation analysis. Table 3 tabulates the results of this study obtained from the analysis. The values of correlations are deemed to be very low when they are under 0.20 ; they are low when they are from 0.20 to 0.40 , moderate from 0.40 to 0.70 , high from 0.70 to 0.90 , and lastly, very high when over 0.90. According to Blean et al. (2009), a very high correlation among the predictors can mean the existence of multicollinearity. In the present study, SA, DA, CS, and JS had low to moderate correlations (refer to Table 3), while no multicollinearity issue existed between the independent variables, as none of them were very highly correlated.

Table 4. Measurement Model Result

\begin{tabular}{|l|c|c|c|c|c|c|}
\hline Constructs & $\begin{array}{c}\text { Unstandardized } \\
\text { Coefficient } \boldsymbol{\beta}\end{array}$ & SD Error & $\begin{array}{c}\text { Standardized } \\
\text { Coefficient Beta }\end{array}$ & t-value & p-value & VIF \\
\hline $\mathrm{SA} \rightarrow \mathrm{JS}$ & -0.167 & 0.052 & -0.171 & -3.201 & 0.002 & 1.023 \\
\hline $\mathrm{DA} \rightarrow \mathrm{JS}$ & 0.489 & 0.061 & 0.431 & 8.045 & 0.000 & 1.023 \\
\hline $\mathrm{SA} \rightarrow \mathrm{CS}$ & -.197 & .052 & -.207 & -3.776 & .000 & 1.023 \\
\hline $\mathrm{DA} \rightarrow \mathrm{CS}$ & .412 & .061 & .371 & 6.775 & .000 & 1.023 \\
\hline $\mathrm{JS} \rightarrow \mathrm{CS}$ & .576 & .047 & .588 & 12.36 & .000 & - \\
\hline
\end{tabular}

Source: own elaboration. 
Table 4 contains the results of the conceptual framework of relationships analysis. The relationships were all significant, with p-values of less than 0.05 , which indicates that surface acting and deep acting have significant relationships with customer satisfaction and job satisfaction. The results also show that job satisfaction has a significant relationship with customer satisfaction. Hypotheses' results are tabulated in the Table 5.

Table 5. Results of Hypotheses Testing (Direct Paths)

\begin{tabular}{|l|c|c|c|}
\hline Hypotheses Path & Standardised Path Coefficients & P-value & Result \\
\hline $\mathrm{SA} \rightarrow \mathrm{JS}$ & -0.171 & $0.00 * *$ & Supported \\
\hline $\mathrm{DA} \rightarrow \mathrm{JS}$ & 0.431 & $0.00^{* *}$ & Supported \\
\hline $\mathrm{SA} \rightarrow \mathrm{CS}$ & -.207 & $0.00 * *$ & Supported \\
\hline $\mathrm{DA} \rightarrow \mathrm{CS}$ & .371 & $0.00^{* *}$ & Supported \\
\hline
\end{tabular}

Note: ** Statistically significant at the $1 \%$ level ( $p$-value $<0.05)$.

Source: own elaboration.

The above table displays the direct impacts hypothesized in $\mathrm{H} 1, \mathrm{H} 2, \mathrm{H} 3$, and $\mathrm{H} 4$ and - based on the results - shows that all the direct relationships are significant and are thus supported. With regards to hypotheses $\mathrm{H} 1$ and $\mathrm{H} 3$, surface acting has a negative relationship with both job satisfaction and customer satisfaction. Similarly, in relation to hypotheses $\mathrm{H} 2$ and $\mathrm{H} 4$, deep acting has a positive relationship with both job satisfaction and customer satisfaction. The results for the moderating and mediating relationship testing, which involves hypotheses $\mathrm{H} 5, \mathrm{H} 6, \mathrm{H} 7$, and H8, are presented in the next section.

Table 6. Results of Mediating Hypotheses Analysis (Job Satisfaction as Mediator)

\begin{tabular}{|l|c|c|c|}
\hline Dependent Variable $\rightarrow$ & $\begin{array}{c}\text { (Step 1) } \\
\text { Job Satisfaction }\end{array}$ & $\begin{array}{c}\text { (Step 2) } \\
\text { Customer Satisfaction }\end{array}$ & $\begin{array}{c}\text { (Step 3) } \\
\text { Customer Satisfaction }\end{array}$ \\
\hline Job Satisfaction & & & $0.515^{* *}$ \\
\hline Surface Acting & $-0.171^{\star *}$ & $-.207^{* *}$ & $-0.118^{* *}$ \\
\hline Deep Acting & $0.431^{* *}$ & $.371^{\star *}$ & $0.149 * *$ \\
\hline F-Statistics & 34.421 & 26.870 & 56.572 \\
\hline Probability (F-Statistics) & 0.000 & 0.000 & 0.000 \\
\hline R-Square & 0.193 & 0.157 & 0.372 \\
\hline
\end{tabular}

Source: own elaboration. 


\section{Results of Mediating Hypotheses}

With regards to hypotheses $\mathrm{H} 5$ and $\mathrm{H} 6$ about the mediating role of job satisfaction on the relationship between surface acting, deep acting, and customer satisfaction, we followed the method developed by Baron and Kenny (1986). The mediating effect exists if the following criteria are met: the independent variable significantly predicts the mediating variable (Step 1), the independent variable significantly predicts the dependent variable (Step 2), and the mediator significantly predicts the outcome variable, with the relationship between the predictor variable and outcome variable being lesser (refer to Step 2). Table 6 clearly shows that the relationships of independent variables (surface acting and deep acting) with a mediator variable (job satisfaction) are significant, which meets the first criterion. In step 2, the independent variables (surface acting and deep acting) are significantly related to the dependent variable (customer satisfaction), which meets the second criterion. In step 3, the mediating variable's (job satisfaction) relationship with the dependent variable (customer satisfaction) is significant, which meets the third criterion, with the direct relationship of independent variables being lesser than that of the mediator and the dependent variable. In step 2, the surface acting coefficient was 0.298 with $\mathrm{p}<.0 .05$, and in step 3 , it increased to 0.216 with $\mathrm{p}<0.05$, thus indicating the mediating role of job satisfaction on the relationship between surface acting and customer satisfaction. Similarly, in step 2, the deep acting coefficient was 0.282 with $\mathrm{p}<0.05$, while in step 3 , it increased to 0.208 with $p<0.05$, thus indicating the mediating role of job satisfaction on the relationship between deep acting and customer satisfaction. Hence, we may state that H5 and H6 are supported.

Table 7. Results of Moderation Hypothesis Analysis (Mentoring as Moderator)

\begin{tabular}{|l|c|c|c|c|c|}
\hline Constructs & $\begin{array}{c}\text { Unstandardized } \\
\text { Coefficient } \beta\end{array}$ & SD Error & $\begin{array}{c}\text { Standardized } \\
\text { Coefficient Beta }\end{array}$ & t-value & P-value \\
\hline SA & -.118 & .138 & -.121 & -.855 & .394 \\
\hline DA & .825 & .143 & .727 & 5.757 & .000 \\
\hline MEN & .728 & .178 & .730 & 4.081 & .000 \\
\hline MEN_X_SA & -.001 & .045 & -.005 & -.028 & .978 \\
\hline MEN_X_DA & -.144 & .051 & -.595 & -2.843 & .005 \\
\hline
\end{tabular}

Source: own elaboration.

The moderating analysis results are displayed in the table above. The interaction of mentoring with deep acting was significant, with the p-value of 0.005 (less than 0.05), 
and the interaction of mentoring with surface acting was insignificant, with the p-value of 0.978, higher than 0.05. Therefore, mentoring moderated the relationship between deep acting and job satisfaction but not between surface acting and job satisfaction, thus supporting H7 but not H8.

\section{Discussion and Conclusion}

This study sought to provide insight into the direct relationship of deep acting and surface acting with customer satisfaction and job satisfaction, with the mediating role of job satisfaction and the moderating role of mentoring. Employees of Jordanian service companies were selected because of the sector's diversity in employment, which means that the sector needs talented and capable people in almost every field of work. The study's conceptual framework proposed the moderating role of mentoring on surface acting and deep acting relationship with job satisfaction. Both direct relationships of surface acting with job satisfaction and deep acting with job satisfaction were supported, with the former in the negative direction and the latter in a positive direction. According to Bono and Vey (2005), surface acting refers to decreased job satisfaction, with deep acting being a non-factor. The majority of studies of this caliber confirms the adverse impact of surface acting on job satisfaction among public service workers (e.g., Hsieh et al., 2012; Sloan, 2014), along with a conclusion that hypocritical acting reflects self-denial, which negatively affects job attitudes (Shamir, 1991).

In a related study, Lee and Ok (2012) reveal that deep acting employees have a higher likelihood of experiencing job satisfaction in comparison to their surface acting colleagues. The present study's results, thus, agree with Lee's and Ok's (2012) findings. In contrast to Kim (2008) and Lee and Ok (2014; 2015), our findings reveal that surface acting leads to tension, stress, poor service quality, burnout, job dissatisfaction, and service misbehavior. In work environment context, the requirement of adhering to rules amplifies emotional burden, as workers must focus on their outward expressions and suppress their actual emotions without resolving them, hence the rise of counterproductive feelings (e.g., sadness, regret, anger, concern, or even fear; Hsieh, 2014). Moreover, surface acting can lead to the feeling of emotional dissonance in employees serving customers when there is the added pressure of psychological strain and emotional distress, which makes employees lose the ability to control emotions. Thus, this study supports the argument that surface acting has a negative relationship with job satisfaction.

Moreover, deep acting promotes genuine feelings when dealing with customers while meeting expected organizational rules. Deep acting is labeled with "good faith," as it 
calls for putting one's self in another's shoes (Diefendorff et al., 2005), which can positively affect customer satisfaction. In this case, our results agree with the prior findings that find a positive relationship between deep acting and customer satisfaction. Moreover, our results support the view that surface acting, which suppresses negative emotions like anger and frustration to present only positive emotions to customers (Grandey, 2003), can lead to negative effects on customer satisfaction.

As for moderating effects, mentoring refers to the mentor being a role model who plays a key role in the protégé's development of value and character. Based on the majority of studies, mentoring enhances the job satisfaction of the mentee (Allen et al., 2004). Through the observation of mentors' attitudes and behaviors, mentees gain an understanding of and begin to identify with the service norms and values of the organization (Ashforth and Saks, 2002). Consequently, the mentees/employees can modify their cognitions and thoughts in order to provide excellent services, meet customer needs, and resolve their issues. This study finds mentoring to have a significant moderating effect on the relationship between deep acting and job satisfaction but not surface acting and job satisfaction. The majority of our results support those reported in the literature and contribute by extending the literature dedicated to the study of variables in relationships.

\section{Limitations and Future Research}

This study is limited to the examination of mentoring as a mediating variable. Future studies should examine training and burnout as mediating variables. Research devoted to examining the effects of EL on the service sector in light of job satisfaction and customer satisfaction is still scarce. Moreover, some focus on the relationship between EL and job performance, but only a few on the influence of emotional labor on employee job satisfaction and customer satisfaction. As this study was conducted among Jordanian service companies, future studies could further test the relationships among them. This study is limited in the number of the study sample, which is 291, which future studies could extend to gain more accurate results. Methodologically, the study used only SPSS analysis and, as such, we recommend that future studies employ SEM for the relationships tested. SEM can more accurately confirm validity and reliability, as it has better statistical tools for this specific purpose.

\section{Author Contributions}

All authors contributed substantially to all aspects of this article. 


\section{Funding}

This research received no external funding.

\section{Conflict of Interest Statement}

The authors declare that the research was conducted in the absence of any commercial or financial relationships that could be construed as a potential conflict of interest.

\section{Ethics Statement}

The study was approved by the ethics committee of the Department of Business, Central South University. Participation was voluntary and actual participation meant a statement of consent.

\section{References}

Abdulaali, A.R., Alnoor, A. and Eneizan, B. (2019). A multi-level study of influence knowledge management small and medium enterprises. Polish Journal of Management Studies, 19(1), 21-31, https://doi.org/10.17512/pjms.2019.19.1.02.

Al-Abrrow, H., Alnoor, A. and Abbas, S. (2019). The Effect of Organizational Resilience and CEO's Narcissism on Project Success: Organizational Risk as Mediating Variable. Organization Management Journal, 16(1), 1-13, https://doi.org/10.1080/15416518.2018.1549468.

Al-Abrrow, H., Alnoor, A. and Abdullah, H. (2018). Socio-technical approach, decision-making environment, and sustainable performance: Role of ERP systems. Interdisciplinary Journal of Information, Knowledge, and Management, 13, 397-415, https://doi.org/10.28945/4149.

Albrecht, K. and Zemke, R. (1985). Service America! Doing Business in the New Economy. Dow Jones-Irwin, Homewood,IL.

Alhamdi, M., Alnoor, A., Eneizan, B., Abdulla, M. and Abdulaali, A.R. (2019). Determinants of the production system time (jit) on reduce waste: Case study in a salsal water company. International Journal of Academic Research in Business and Social Sciences, 9(7), 17-32.

Alhamdi, M., Noor, R.M.A.S., Abdulla, M., Alnoor, A. and Eneizan, B. (2019). How Does Financial Analysis Influence the Firm's Failure of Iraqi Private Sector? The Journal of Social Sciences Research, 5(9), 1321-1328, https://doi.org/10.32861/jssr.59.1321.1328.

Allen, T.D., Eby, L.T., Poteet, M.L., Lentz, E. and Lima, L. (2004). Career benefits associated with mentoring for protégés: A meta-analysis. Journal of Applied Psychology, 89(1), 127-136, https://doi.org/10.1037/0021-9010.89.1.127.

Almeida, D.M. (2005). Resilience and vulnerability to daily stressors assessed via diary methods. Current Directions in Psychological Science, 14(2), 64-68, https://doi.org/10.1111/j.0963-7214.2005.00336.x

Alnoor, A., Eneizan, B., Makhamreh, H. Z. and Rahoma, I.A. (2018). The effect of reverse logistics on sustainable manufacturing. International Journal of Academic Research in Accounting, Finance and Management Sciences, 9(1), 71-79.

Ashforth, B.E. and Humphrey, R.H. (1993). Emotional labor in service roles: The influence of identity. Academy of Management Review, 18(1), 88-115, https://doi.org/10.5465/amr.1993.3997508. 
Ashforth, B.E. and Saks, A.M. (2002). Feeling your way: Emotion and organizational entry. In: R.G. Lord, R.J. Klimoski and R. Kanfer (eds.), Emotions in the Workplace: Understanding the Structure and Role of Emotions in Organizational Behavior. Jossey-Bass.

Baron, R.M. and Kenny, D.A. (1986). The moderator-mediator variable distinction in social psychological research: Conceptual, strategic, and statistical considerations. Journal of Personality and Social Psychology, 51(6), 1173, https://doi.org/10.1037/0022-3514.51.6.1173.

Bitner, M.J. (1990). Evaluating service encounters: the effects of physical surroundings and employee responses. Journal of Marketing, 69-82, https://doi.org/10.1177/002224299005400206.

Bitner, M.J., Booms, B.H. and Tetreault, M.S. (1990). The service encounter: diagnosing favorable and unfavorable incidents. The Journal of Marketing, 71-84, https://doi.org/10.1177/002224299005400105.

Bolton, R.N. and Drew, J.H. (1991). A multistage model of customers' assessments of service quality and value. Journal of Consumer Research, 17(4), 375-384, https://doi.org/10.1086/208564.

Bono, J.E. and Vey, M.A. (2005). Toward understanding emotional management at work: A quantitative review of emotional labor research. In: Emotions in organizational behavior. Psychology Press.

Bowen, J. (1990). Development of a taxonomy of services to gain strategic marketing insights. Journal of the Academy of Marketing Science, 18(1), 43-49, https://doi.org/10.1007/BF02729761.

Bozionelos, N. and Kiamou, K. (2008). Emotion work in the Hellenic frontline services environment: How it relates to emotional exhaustion and work attitudes. The International Journal of Human Resource Management, 19(6), 1108-1130, https://doi.org/10.1080/09585190802051410.

Brotheridge, C.M. and Grandey, A.A. (2002). Emotional labor and burnout: Comparing two perspectives of "people work". Journal of Vocational Behavior, 60(1), 17-39, https://doi.org/10.1006/jvbe.2001.1815.

Brotheridge, C.M. and Lee, R.T. (2002). Testing a conservation of resources model of the dynamics of emotional labor. Journal of Occupational Health Psychology, 7(1), 57-67, https://doi.org/10.1037/1076-8998.7.1.57.

Chen, Z., Sun, H., Lam, W., Hu, Q., Huo, Y. and Zhong, J.A. (2012). Chinese hotel employees in the smiling masks: Roles of job satisfaction, burnout, and supervisory support in relationships between emotional labor and performance. The International Journal of Human Resource Management, 23(4), 826-845, https://doi.org/10.1080/09585192.2011.579918.

Chi, N.W. and Wang, I.A. (2016). The relationship between newcomers' emotional labor and service performance: the moderating roles of service training and mentoring functions. The International Journal of Human Resource Management, 1-29, https://doi.org/10.1080/09585192.2016.1259645.

Choo, S.S., Hendrik, H. and Keng-Howe, I.C. (2009). Life values and job satisfaction: Comparing local managers to the Japanese and Chinese expatriates in Singapore. International Journal of Business Studies: A Publication of the Faculty of Business Administration, 17(1), 61-106.

Cole, M.S., Bruch, H. and Vogel, B. (2006). Emotion as mediators of the relations between perceived supervisor support and psychological hardiness on employee cynicism. Journal of Organizational Behavior, 27(4), 463-484, https://doi.org/10.1002/job.381.

Collins, P.M. (1994). Does mentorship among social workers make a difference? An empirical investigation of career outcomes. Social Work, 39(4), 413-419.

Demerouti, E., Mostert, K. and Bakker, A.B. (2010). Burnout and work engagement: a thorough investigation of the independency of both constructs. Journal of Occupational Health Psychology, 15(3), 209-222, https://doi.org/10.1037/a0019408.

Dick, A. (2011). An Investigation into the Consequences of Performing Emotional Labour in Mental Health Care, master's thesis, University of Waterloo. 
Diefendorff, J.M. and Richard, E.M. (2003). Antecedents and consequences of emotional display rule perceptions. Journal of Applied Psychology, 88(2), 284-294, https://doi.org/10.1037/0021-9010.88.2.284.

Diefendorff, J.M., Croyle, M.H. and Gosserand, R.H. (2005). The dimensionality and antecedents of emotional labor strategies. Journal of Vocational Behavior, 66(2), 339-357, https://doi.org/10.1016/j.jvb.2004.02.001.

Dreher, G.F. and Ash, R.A. (1990). A comparative study of mentoring among men and women in managerial, professional, and technical positions. Journal of Applied Psychology, 75(5), 539-549, https://doi.org/10.1037/0021-9010.75.5.539.

Erdem, F. and Aytemur, J.Ö. (2008). Mentoring-A relationship based on trust: Qualitative research. Public Personnel Management, 37(1), 55-65, https://doi.org/10.1177/009102600803700104.

Ficko-Blean, E., Gregg, K.J., Adams, J.J., Hehemann, J.H., Czjzek, M., Smith, S.P. and Boraston, A.B. (2009). Portrait of an enzyme, a complete structural analysis of a multimodular -N-acetylglucosaminidase from Clostridium perfringens. Journal of Biological Chemistry, 284(15), 9876-9884, https://doi.org/10.1074/jbc.M808954200.

Garcia, S.I., Pieters, R., Zeelenberg, M. and Bigne, E. (2012) When satisfied consumers do not return: varietyseeking's effect on short- and long-term intentions. Psychology and Marketing, 29(1),15-24, https://doi.org/10.1002/mar.20431.

Ghalandari, K., Jogh, M.G.G., Imani, M. and Nia, L.B. (2012). The effect of emotional labor strategies on employees job performance and organizational commitment in hospital sector: moderating role of emotional intelligence in Iran. World Applied Sciences Journal, 17(3), 319-326.

Gosserand, R.H. and Diefendorff, J.M. (2005). Emotional display rules and emotional labor: the moderating role of commitment. Journal of Applied Psychology, 90(6), 1256-1264, https://doi.org/10.1037/0021-9010.90.6.1256.

Grandey, A.A. (2000). Emotional regulation in the workplace: A new way to conceptualize emotional labor. Journal of Occupational Health Psychology, 5(1), 95-110, https://doi.org/10.1037/1076-8998.5.1.95.

Grandey, A.A. (2003). When "the show must go on": Surface acting and deep acting as determinants of emotional exhaustion and peer-rated service delivery. Academy of Management Journal, 46(1), 86-96, https://doi.org/10.5465/30040678.

Grandey, A.A., Fisk, G.M., Mattila, A.S., Jansen, K.J. and Sideman, L.A. (2005). Is "service with a smile" enough? Authenticity of positive displays during service encounters. Organizational Behavior and Human Decision Processes, 96(1), 38-55, https://doi.org/10.1016/j.obhdp.2004.08.002.

Groth, M., Hennig-Thurau, T. and Walsh, G. (2009). Customer reactions to emotional labor: The roles of employee acting strategies and customer detection accuracy. Academy of Management Journal, 52(5), 958-974, https://doi.org/10.5465/amj.2009.44634116.

Grove, S.J. and Fisk, R.P. (1992). The service experience as theater. ACR North American Advances.

Guo, X., Ling, K.C. and Liu, M. (2012). Evaluating factors influencing customer satisfaction towards onlineshopping in China. Asian Social Science, 8(13), 40-50, https://doi.org/10.5539/ass.v8n13p40.

Hennig-Thurau, T., Groth, M., Paul, M. and Gremler, D.D. (2006). Are all smiles created equal? How emotional contagion and emotional labor affect service relationships. Journal of Marketing, 70(3), 58-73, https://doi.org/10.1509/jmkg.

Hochschild, A.R. (1983). The managed heart: Commercialization of human feeling. Berkeley: University of California Press. 
Hombrados-Mendieta, I. and Cosano-Rivas, F. (2013). Burnout, workplace support, job satisfaction and life satisfaction among social workers in Spain: A structural equation model. International Social Work, 56(2), 228-246, https://doi.org/10.1177/0020872811421620.

Howard, J.A. and Sheth, J.N. (1969). The theory of buyer behavior (No. 658.834 H6).

Hsieh, C.W. (2014). Burnout among public service workers: The role of emotional labor requirements and job resources. Review of Public Personnel Administration, 34(4), 379-402, https://doi.org/10.1177/0734371X12460554.

Hsieh, C.W., Jin, M.H. and Guy, M.E. (2012). Consequences of work-related emotions: Analysis of a cross-section of public service workers. The American Review of Public Administration, 42(1), 39-53, https://doi.org/10.1177/0275074010396078.

$\mathrm{Hu}$, C., Pellegrini, E.K. and Scandura, T.A. (2011). Measurement invariance in mentoring research: A cross-cultural examination across Taiwan and the US. Journal of Vocational Behavior, 78(2), 274-282, https://doi.org/10.1016/j.jvb.2010.10.003.

Hülsheger, U.R. and Schewe, A.F. (2011). On the costs and benefits of emotional labor: A meta-analysis of three decades of research. Journal of Occupational Health Psychology, 16(3), 361-389, https://doi.org/10.1037/a0022876.

Iacobucci, D., Ostrom, A. and Grayson, K. (1995). Distinguishing service quality and customer satisfaction: the voice of the consumer. Journal of Consumer Psychology, 4(3), 277-303, https://doi.org/10.1207/s15327663jcp0403_04.

Johnson, H.A.M. and Spector, P.E. (2007). Service with a smile: Do emotional intelligence, gender, and autonomy moderate the emotional labor process? Journal of Occupational Health Psychology, 12(4), 319, https://doi.org/10.1037/1076-8998.12.4.319.

Johnson, W.B. and Ridley, C.R. (2015). The elements of mentoring. St. Martin's Press.

Jung, J.H. and Tak, J. (2008). The effects of perceived career plateau on employees' attitudes: Moderating effects of career motivation and perceived supervisor support with Korean employees. Journal of Career Development, 35(2), 187-201, https://doi.org/10.1177/0894845308325648.

Kaur, S. and Malodia, L. (2017). Influence of Emotional Labour on Job Satisfaction among Employees of Private Hospitals: A Structural Equation Modelling Approach. Journal of Health Management, 19(3), 456-473, https://doi.org/10.1177/0972063417717899.

Khristianto W, Kertahadi I. and Suyadi, I. (2012). The influence of information, system and service on customersatisfaction and loyalty in online shopping. International Journal of Academic Research, 4(2), 28-32.

Kim, W., Lee, K. and Lee, K. (2012). Job environment and stress of emotional workers. Korean Sociology, $46(2), 123-149$.

Kim, H.J. (2008). Hotel service providers' emotional labor: The antecedents and effects on burnout. International Journal of Hospitality Management, 27(2), 151-161, https://doi.org/10.1016/j.ijhm.2007.07.019.

Kim, S.Y., Chang, S.J., Kim, H.R. and Roh, J.H. (2002). A study on the relationship between emotional labor and depressive symptoms among Korean industrial service employees. Korean Journal of Occupational and Environmental Medicine, 14(3), 227-235,

https://doi.org/10.35371/kjoem.2002.14.3.227.

Kram, K.E. (1985). Mentoring at work: Developing relationships in organizational life. Glenview, IL: Scott, Foresman.

Kram, K.E. (1985a). Mentoring at work: developmental relationships in or-ganizational life. Glenview, IL: Scott, Foresman. 
Kundu, S. and Datta, S.K. (2015). Impact of trust on the relationship of e-service quality and customer satisfaction. EuroMed Journal of Business, 10(1), 21-46, https://doi.org/10.1108/EMJB-10-2013-0053

Lee, C.D. and del Carmen Montiel, E. (2011). The correlation of mentoring and job satisfaction: A pilot study of mental health professionals. Community Mental Health Journal, 47(4), 482-487, https://doi.org/10.1007/s10597-010-9356-7.

Lee, J.J. and Ok, C.M. (2012). Reducing burnout and enhancing job satisfaction: Critical role of hotel employees' emotional intelligence and emotional labor. International Journal of Hospitality Management, 31(4), 1101-1112, https://doi.org/10.1016/j.ijhm.2012.01.007.

Lee, J. and Ok, C.M. (2015). Hotel employee work engagement and its consequences. Journal of Hospitality Marketing \& Management, 25(2), 133-166, https://doi.org/10.1080/19368623.2014.994154.

Leiter, M.P., Hakanen, J.J., Ahola, K., Toppinen Tanner, S., Koskinen, A. and Väänänen, A. (2013). Organizational predictors and health consequences of changes in burnout: A 12 year cohort study. Journal of Organizational Behavior, 34(7), 959-973, https://doi.org/10.1002/job.1830.

Lentz, E. and Allen, T.D. (2009). The role of mentoring others in the career plateauing phenomenon. Group \& Organization Management, 34(3), 358-384, https://doi.org/10.1177/1059601109334027.

Lim, S.S., Lee, W., Hong, K., Jeung, D., Chang, S.J. and Yoon, J.H. (2016). Facing complaining customer and suppressed emotion at worksite related to sleep disturbance in Korea. Journal of Korean Medical Science, 31(11), 1696-1702, https://doi.org/10.3346/jkms.2016.31.11.1696.

Lin, Y.W. and Chang, W.P. (2015). Physician Emotional Labor and Job Performance: The Mediating Effects of Emotional Exhaustion. Journal of Health Management, 17(4), 446-457, https://doi.org/10.1177/0972063415606281.

Liu, Y., Perrewé, P.L., Hochwarter, W.A. and Kacmar, C.J. (2004). Dispositional antecedents and consequences of emotional labor at work. Journal of Leadership \& Organizational Studies, 10(4), 12-25, https://doi.org/10.1177/107179190401000402.

Morris, J.A. and Feldman, D.C. (1996). The dimensions, antecedents, and consequences of emotional labor. Academy of Management Review, 21(4), 986-1010, https://doi.org/10.5465/amr.1996.9704071861.

Oliver, R.L. (1993). A Conceptual Model of Service Quality and Service Satisfaction: Comparative Goals, Different Concepts. In: Advances in service marketing and management, Vol. 2. Greenwich, CT: JAI Press.

Pallant, C. (2011). Demystifying Disney: a history of Disney feature animation. Bloomsbury Publishing USA, https://doi.org/10.5040/9781628928655.

Piccolo, R.F., Greenbaum, R., Hartog, D.N.D. and Folger, R. (2010). The relationship between ethical leadership and core job characteristics. Journal of Organizational Behavior, 31(2-3), 259-278, https://doi.org/10.1002/job.627.

Pugh, S.D. (2001). Service with a smile: Emotional contagion in the service encounter. Academy of Management Journal, 44(5), 1018-1027, https://doi.org/10.5465/3069445.

Purcell, K. (1993). Equal opportunities in the hospitality industry: custom and credentials. International Journal of Hospitality Management, 12(2), 127-140, https://doi.org/10.1016/0278-4319(93)90005-T.

Rafaeli, A. and Sutton, R.I. (1987). Expression of emotion as part of the work role. Academy of Management Review, 12(1), 23-37, https://doi.org/10.5465/amr.1987.4306444.

Sáenz, M.J., Knoppen, D. and Tachizawa, E.M. (2018). Building manufacturing flexibility with strategic suppliers and contingent effect of product dynamism on customer satisfaction. Journal of Purchasing and Supply Management, 24(3), 238-246, https://doi.org/10.1016/j.pursup.2017.07.002. 
Scandura, T.A. and Ragins, B.R. (1993). The effects of sex and gender role orientation on mentorship in male-dominated occupations. Journal of Vocational Behavior, 43(3), 251-265, https://doi.org/10.1006/jvbe.1993.1046.

Scandura, T.A. and Viator, R.E. (1994). Mentoring in public accounting firms: An analysis of mentor-protégé relationships, mentorship functions, and protégé turnover intentions. Accounting, Organizations and Society, 19(8), 717-734, https://doi.org/10.1016/0361-3682(94)90031-0.

Schaufeli, W.B. and Taris, T.W. (2014). A critical review of the Job Demands-Resources Model: Implications for improving work and health. In: Bridging occupational, organizational and public health. Springer Netherlands, https://doi.org/10.1007/978-94-007-5640-3_4.

Schmit, M.J. and Allscheid, S.P. (1995). Employee attitudes and customer satisfaction: Making theoretical and empirical connections. Personnel Psychology, 48(3), 521-536, https://doi.org/10.1111/j.1744-6570.1995.tb01768.x.

Schneider, B. and Bowen, D.E. (1985). Employee and customer perceptions of service in banks: Replication and extension. Journal of Applied Psychology, 70(3), 423-433, https://doi.org/10.1037/0021-9010.70.3.423.

Shafer, W.E. (2002). Ethical pressure, organizational-professional conflict, and related work outcomes among management accountants. Journal of Business Ethics, 38(3), 261-273, https://doi.org/10.1023/A:1015876809254.

Shamir, B. (1991). Meaning, self and motivation in organizations. Organization Studies, 12(3), 405-424, https://doi.org/10.1177/017084069101200304.

Sloan, M.M. (2014). The consequences of emotional labor for public sector workers and the mitigating role of self-efficacy. The American Review of Public Administration, 44(3), 274-290, https://doi.org/10.1177/0275074012462864.

Springer, G.J. (2011). A study of job motivation, satisfaction, and performance among bank employees. Journal of Global Business Issues, 5(1), 29.

Stathopoulou, A. and Balabanis, G. (2016). The effects of loyalty programs on customer satisfaction, trust, and loyalty toward high-and low-end fashion retailers. Journal of Business Research, 69(12), 5801-5808, https://doi.org/10.1016/j.jbusres.2016.04.177.

Tandon, U., Kiran, R. and Sah, A.N. (2018). The influence of website functionality, drivers and perceived risk on customer satisfaction in online shopping: an emerging economy case. Information Systems and e-Business Management, 16(1), 57-91, https://doi.org/10.1007/s10257-017-0341-3.

Ten Brummelhuis, L.L., Bakker, A.B., Hetland, J. and Keulemans, L. (2012). Do new ways of working foster work engagement? Psicothema, 24(1), 113-120.

Thomas, C.H. and Lankau, M.J. (2009). Preventing burnout: The effects of LMX and mentoring on socialization, role stress, and burnout. Human Resource Management, 48(3), 417-432, https://doi.org/10.1002/hrm.20288.

Totterdell, P. and Holman, D. (2003). Emotion regulation in customer service roles: Testing a model of emotional labor. Journal of Occupational Health Psychology, 8(1), 55-73, https://doi.org/10.1037/1076-8998.8.1.55.

Tsai, W.C. (2001). Determinants and consequences of employee displayed positive emotions. Journal of Management, 27(4), 497-51, https://doi.org/10.1177/014920630102700406.

Van den Heuvel, M., Demerouti, E., Bakker, A.B. and Schaufeli, W.B. (2013). Adapting to change: The value of change information and meaning-making. Journal of Vocational Behavior, 83(1), 11-21, https://doi.org/10.1016/j.jvb.2013.02.004.

Weng, R.H., Huang, C.Y., Tsai, W.C., Chang, L.Y., Lin, S.E. and Lee, M.Y. (2010). Exploring the impact of mentoring functions on job satisfaction and organizational commitment of new staff nurses. BMC Health Services Research, 10(1), 210-240, https://doi.org/10.1186/1472-6963-10-240. 
Wharton, A.S. and Erickson, R.I. (1993). Managing emotions on the job and at home: Understanding the consequences of multiple emotional roles. Academy of Management Review, 18(3), 457-486, https://doi.org/10.5465/amr.1993.9309035147.

Wilson, A., Zeithaml, V.A., Bitner, M.J. and Gremler, D.D. (2012). Services marketing: Integrating customer focus across the firm (No. 2nd Eu). McGraw Hill.

Yang, F.H. and Chang, C.C. (2008). Emotional labour, job satisfaction and organizational commitment amongst clinical nurses: A questionnaire survey. International Journal of Nursing Studies, 45(6), 879-887, https://doi.org/10.1016/j.ijnurstu.2007.02.001.

Yao, Y., Dresner, M. and Palmer, J.W. (2009). Impact of boundary spanning information technology and position in chain on firm performance. Journal of Supply Chain Management, 45(4), 3-16, https://doi.org/10.1111/j.1745-493X.2009.03172.x.

Young, A.M. and Perrewé, P.L. (2004). The role of expectations in the mentoring exchange: An analysis of mentor and protégé expectations in relation to perceived support. Journal of Managerial Issues, 16(1), 103-126.

Yuksel, A. and Yuksel, F. (2001). Measurement and management issues in customer satisfaction research: Review, critique and research agenda: Part one. Journal of Travel \& Tourism Marketing, 10(4), 47-80, https://doi.org/10.1300/J073v10n04_03.

Zhang, Q., Vonderembse, M.A. and Lim, J.S. (2003). Manufacturing flexibility: defining and analyzing relationships among competence, capability, and customer satisfaction. Journal of Operations Management, 21(2), 173-191, https://doi.org/10.1016/S0272-6963(02)00067-0. 